\title{
Effect of Lupinus Growth Factor on the in vitro Growth of Embryos of Various Plants and Carrot Root Tissue
}

\author{
by Satoshi Matsubara*
}

Received October 5, 1964

Since coconut milk was shown to stimulate the growth of Datura embryo in vitro $^{(1)}$, the use of it has become common in the embryo and the tissue culture of various plants ${ }^{2-8}$. Similar growth-promoting factors were found in a number of plant materials ${ }^{9-12)}$.

In the present study the application of embryo factor obtained from young $L u$. pinus seeds ${ }^{12)}$ to the embryo culture of various plants other than Datura and to callus tissue of carrot root was investigated, and the distribution of embryo factors in various plant materials was examined.

\section{Materials and Methods}

Young embryos of Datura tatula, Pharbitis nil, Bidens biternata, Antirrhinum majus, Lupinus luteus, Stellaria media, Brassica campestris, Capsella bursa-pastoris, Astragalus sinicus, Vicia faba, Iris pseudoacorus, Vicia sativa, Triticum aestivum, and young hybrid embryos from a genetically incompatible cross of Brassica pekinensis $(2 n=40) \times B$. chinensis $(2 n=20)$, and callus tissue from the root of Daucus carota were cultured. For the aseptic isolation of embryos, fruit of Datura was treated with 80 per cent ethanol for four minutes. The fruits of other plants and carrot root were treated additionally also with 10 per cent calcium hypochlorite solution for $20 \mathrm{mi}$ nutes. Embryos were isolated as described by Van Overbeek et al. ${ }^{1)}$ Discs of carrot root of $4 \mathrm{~mm}$ diameter and $2 \mathrm{~mm}$ thickness were prepared with a cork borer and a knife.

For embryo culture, the basal medium contained the modified White's solution ${ }^{122}$, $40 \mathrm{~g}$ sucrose, and $9 \mathrm{~g}$ agar per liter, unless otherwise stated. The medium was sterilized by autoclaving at $1.0 \mathrm{~kg} / \mathrm{cm}^{2}$ overpressure for 10 minutes. For the tissue culture, the basal medium, of which sucrose concentration was $20 \mathrm{~g} / l$, contained additionally $2 \mathrm{mg}$ IAA, $3 \mathrm{mg}$ glycine, $0.5 \mathrm{mg}$ nicotinic acid, $0.1 \mathrm{mg}$ thiamine- $\mathrm{HCl}$, and $0.1 \mathrm{mg}$ pyridoxine- $\mathrm{HCl}$, and the medium was steam-sterilized at $100^{\circ}$ for one hour. The seed diffusates of Lupinus luteus, Glycine soja, Phaseolus vulgaris var. humilis and "Black Valentine", Pisum sativum, Arachis hypogaea, Canavalia ensiformis, and fruit diffusate of Brassica campestris were prepared as reported in the previous paper ${ }^{12)}$. The Lupinus diffusate was autoclaved with the basal medium, unless otherwise stated. The diffusates of other plants were sterilized with Seitz-filter and added aseptically to the autoclaved basal medium shortly before solidification.

Young embryos of Datura were cultured at $30^{\circ}$ in darkness for 5 days, and those of other plants at $26^{\circ}$ under continuous illumination of fluorescent lamps. The growth

* Laboratory of Applied Botany, Faculty of Agriculture, Kyoto University, Kyoto, Japan. Present address: Biological Laboratory, Kyoto Prefectural University, Shimogamo, Kyoto, Japan. 
of embryos was expressed by the final length in $\mathrm{mm}$ or the "growth value" (final length/initial length). In the tissue culture, discs of carrot root tissue were grown for 8 weeks on the basal medium with $2 \mathrm{~g} / l$ yeast extract at $26^{\circ}$ under continuous illumination. Every two weeks the cultures were transferred to the fresh medium. Callus tissue, which was produced on cultured discs, was isolated and cultured on the medium to be tested. Test tubes with $10 \mathrm{ml}$ of agar medium and one callus piece each were maintained at $26^{\circ}$ in darkness for 23 days. The growth of the tissue was expressed in $\mathrm{mg}$ by final fresh and dry weights.

\section{Results}

\section{Experiments with Datura embryo}

i) Effect of the concentration of Lupinus diffusate: Young embryos of $0.22 \mathrm{~mm}$ in length were cultured on the media containing various concentrations of Lupinus diffusate. The diffusate, which was sterilized with Seitz-filter in this experiment, was tested at the concentrations corresponding to $0.5,1,5,10,20$, and $50 \mathrm{~g}$ of young Lupinus seeds per $100 \mathrm{~m} l$ of the medium (Fig. 1).

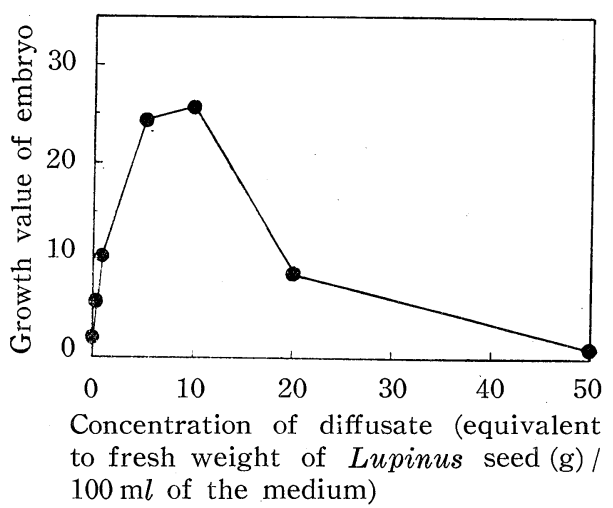

Fig. 1. Growth response of Datura embryos to various concentrations of Lupinus diffusate added to the medium. Initial length of embryos was about $0.22 \mathrm{~mm}$.
On the basal medium without the diffusate, the growth value of embryo was 2.4. With increasing concentration of the diffusate the growth value increased. At the concentration corresponding to $10 \mathrm{~g}$ seeds per $100 \mathrm{~m} l$ of the medium, the embryos grew most vigorously, showing the maximum value of 25.4. With higher concentration of the diffusate, the embryos became thicker, and the root initiation was extremely retarded. At the highest concentration, the growth of embryos was inhibited completely. In the following experiments the $\mathrm{Lu}$ pinus diffusate was used at the concentration equivalent to $5-10 \mathrm{~g}$ of seeds per $100 \mathrm{ml}$ of the medium.

ii) Effect of sterilization method of the diffusate: To learn the heat stability of embryo factor in the Lupinus diffusate and its suitable sterilization method, Datura embryos of $0.22 \mathrm{~mm}$ were cultured on the basal medium, on that with autoclaved diffusate and also with Seitz-filtered diffusate. The growth values were found to be $4.4,25.8$ and 22.5 , respectively.

iii) Growth response of embryos of various ages to Lupinus diffusate: It was reported that casein hydrolysate ${ }^{13)}$ and $\mathrm{NH}_{4} \mathrm{NO}_{3}{ }^{14)}$ were effective only to the young embryos, but not to the older ones. In the present experiment four groups of $D a$ tura embryos in different developmental stages, at which they were $0.23,0.65,1.29$ and $2.30 \mathrm{~mm}$ long, were isolated. They were cultured on the media with and without Lupinus diffusate for 3 days only in this experiment (Fig. 2).

On the basal medium, the growth values of four different age groups of embryos 
Table 1. Effect of Lupinus diffusate and casein hydrolysate on the growth of embryos of various plants. Lupinus diffusate obtained from $8-10 \mathrm{~g}$ of seed or $1000 \mathrm{ppm}$ of casein hydrolysate was added to the basal medium and autoclaved. Embryos of Pharbitis were observed on the 2nd day from the start of culture and those of other plants on the 5 th day.

\begin{tabular}{|c|c|c|c|c|c|}
\hline Plants & Additive & $\begin{array}{l}\text { Number } \\
\text { of } \\
\text { embryos } \\
\text { used }\end{array}$ & $\begin{array}{l}\text { Number } \\
\text { of } \\
\text { growing } \\
\text { embryos }\end{array}$ & $\begin{array}{l}\text { Initial } \\
\text { length } \\
(\mathrm{mm})\end{array}$ & $\begin{array}{l}\text { Final } \\
\text { length } \\
(\mathrm{mm})\end{array}$ \\
\hline $\begin{array}{l}\text { Pharbitis } \\
\text { nil }\end{array}$ & $\begin{array}{l}{\overline{\text { casein }}^{\dagger}}_{\text {hydrolysate }} \\
\text { Lupinus diffusate }\end{array}$ & $\begin{array}{l}3 \\
4 \\
5\end{array}$ & $\begin{array}{l}3 \\
4 \\
5\end{array}$ & $\begin{array}{l}0.76 \\
0.75 \\
0.79\end{array}$ & $\begin{array}{l}1.07 \\
1.30 \\
2.14\end{array}$ \\
\hline $\begin{array}{l}\text { Bidens } \\
\quad \text { biternata }\end{array}$ & $\begin{array}{l}- \\
\text { casein } \\
\text { hydrolysate } \\
\text { Lupinus diffusate }\end{array}$ & $\begin{array}{l}7 \\
8 \\
6\end{array}$ & $\begin{array}{l}7 \\
8 \\
6\end{array}$ & $\begin{array}{l}0.64 \\
0.68 \\
0.67\end{array}$ & $\begin{array}{l}1.03 \\
2.40 \\
1.60\end{array}$ \\
\hline $\begin{array}{l}\text { Antirrhinum } \\
\text { majus }\end{array}$ & $\begin{array}{l}\text { casein } \\
\text { hydrolysate } \\
\text { Lupinus diffusate }\end{array}$ & $\begin{array}{l}8 \\
8 \\
8\end{array}$ & $\begin{array}{l}7 \\
6 \\
5\end{array}$ & $\begin{array}{l}0.55 \\
0.50 \\
0.55\end{array}$ & $\begin{array}{l}1.26 \\
1.04 \\
1.76\end{array}$ \\
\hline $\begin{array}{l}\text { Lupinus } \\
\text { luteus }\end{array}$ & $\begin{array}{l}\text { decolorized } \\
\text { Lupinus diffusate } \\
\text { Lupinus diffusate }\end{array}$ & $\begin{array}{l}7 \\
7 \\
6\end{array}$ & $\begin{array}{l}4 \\
7 \\
6\end{array}$ & $\begin{array}{l}1.13 \\
0.96 \\
1.04\end{array}$ & $\begin{array}{l}1.89 \\
3.86 \\
2.58\end{array}$ \\
\hline $\begin{array}{l}\text { Stellaria } \\
\quad \text { media }\end{array}$ & $\begin{array}{l}\text { decolorized } \\
\text { Lupinus diffusate } \\
\text { Lupinus diffusate }\end{array}$ & $\begin{array}{l}13 \\
13 \\
13\end{array}$ & $\begin{array}{l}8 \\
9 \\
6\end{array}$ & $\begin{array}{l}0.39 \\
0.36 \\
0.41\end{array}$ & $\begin{array}{l}2.79 \\
3.01 \\
1.25\end{array}$ \\
\hline $\begin{array}{l}\text { Brassica } \\
\quad \text { campestris }\end{array}$ & $\begin{array}{l}\text { Lupinus } \\
\text { diffusate }\end{array}$ & $\begin{array}{r}9 \\
11\end{array}$ & $\begin{array}{r}8 \\
10\end{array}$ & $\begin{array}{l}0.41 \\
0.31\end{array}$ & $\begin{array}{l}0.99 \\
2.91\end{array}$ \\
\hline $\begin{array}{l}\text { Capsella } \\
\text { bursa- } \\
\text { pastoris }\end{array}$ & $\begin{array}{l}\text { Lupinus } \\
\text { diffusate }\end{array}$ & $\begin{array}{l}9 \\
9\end{array}$ & $\begin{array}{l}8 \\
7\end{array}$ & $\begin{array}{l}0.30 \\
0.30\end{array}$ & $\begin{array}{l}1.01 \\
3.22\end{array}$ \\
\hline $\begin{array}{l}\text { Astragalus } \\
\text { sinicus }\end{array}$ & $\begin{array}{l}\text { Lupinus } \\
\text { diffusate }\end{array}$ & $\begin{array}{r}9 \\
11\end{array}$ & $\begin{array}{r}9 \\
11\end{array}$ & $\begin{array}{l}0.42 \\
0.39\end{array}$ & $\begin{array}{l}1.34 \\
1.56\end{array}$ \\
\hline $\begin{array}{l}\text { Vicia } \\
\quad \text { faba }\end{array}$ & $\begin{array}{l}\text { Lupinus } \\
\text { diffusate }\end{array}$ & $\begin{array}{l}3 \\
7\end{array}$ & $\begin{array}{l}3 \\
3\end{array}$ & $\begin{array}{l}0.87 \\
0.87\end{array}$ & $\begin{array}{l}1.10 \\
1.20\end{array}$ \\
\hline $\begin{array}{l}\text { Vicia } \\
\quad \text { sativa }\end{array}$ & $\begin{array}{l}\text { Lupinus } \\
\text { diffusate }\end{array}$ & $\begin{array}{l}12 \\
12\end{array}$ & $\begin{array}{l}0 \\
0\end{array}$ & $\begin{array}{l}0.24 \\
0.24\end{array}$ & $\begin{array}{l}0.24 t+t \\
0.24 t+t\end{array}$ \\
\hline $\begin{array}{l}\text { Iris } \\
\quad \text { pseudoacorus }\end{array}$ & $\begin{array}{l}\text { Lupinus } \\
\text { diffusate }\end{array}$ & $\begin{array}{l}6 \\
8\end{array}$ & $\begin{array}{l}6 \\
0\end{array}$ & $\begin{array}{l}2.35 \\
2.30\end{array}$ & 2.30tt \\
\hline $\begin{array}{l}\text { Brassica } \\
\text { pekinensis } \times \\
\text { Brassica } \\
\quad \text { chinensis }\end{array}$ & $\begin{array}{l}\text { Lupinus } \\
\text { diffusate }\end{array}$ & $\begin{array}{l}12 \\
20\end{array}$ & 12 & 0.18 & 1.09 \\
\hline
\end{tabular}

Control.

$\dagger$ All embryos grew into healthy seedlings, but final length was not measured.

t†t All embryos did not grow. 


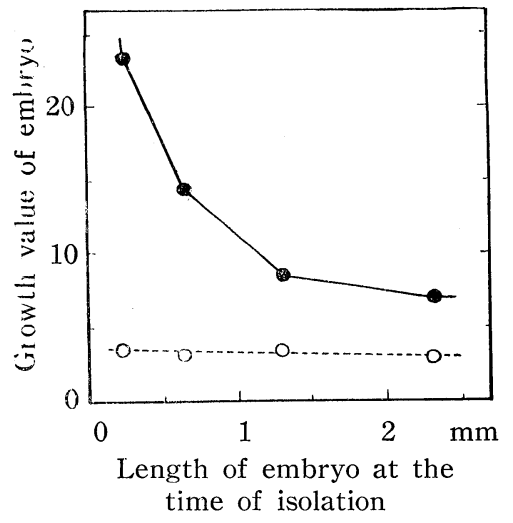

Fig. 2. Growth of young Datura embryos of various ages on the media with (solid line) and without (dotted line) Lupinus diffusate at three-days culture.
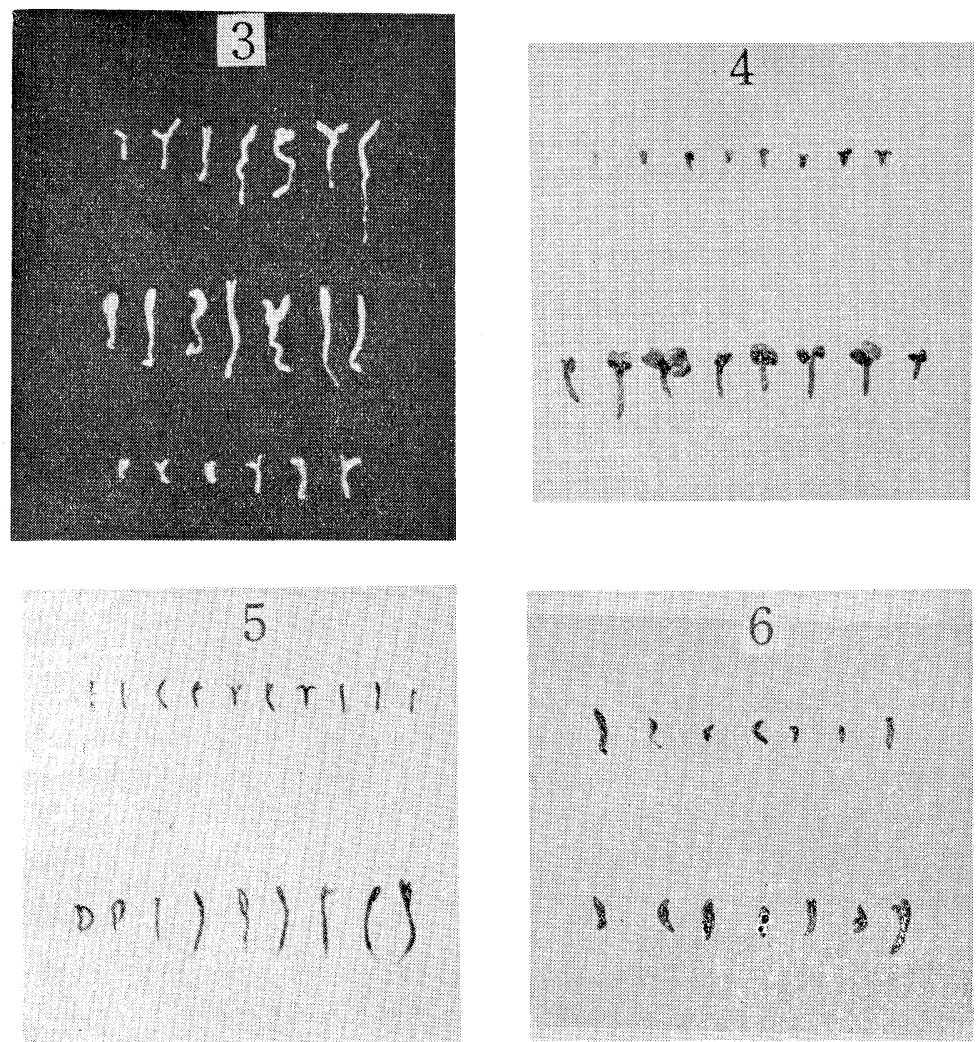

Figs. 3-6. Young embryos of various plants cultured for 5 days. Fig. 3, Stellaria media, ca. $2 \times$. Upper, control; middle, decolorized Lupinus diffusate; lower, Lupinus diffusate. Fig. 4, Brassica campestris, ca. 1.5×. Fig. 5, Capsella bursa-pastoris, ca. $1.5 \times$. Fig. 6, Astragalus sinicus, ca. $1.5 \times$. Upper, control; lower, Lupinus diffusate. 
were approximately the same. On the Lupinus medium, the growth values of embryos decreased from 23.4 to 6.9 with advancing ages, indicating that the diffusate promoted the growth of younger embryos more efficiently. To very young embryos less than $0.08 \mathrm{~mm}$ long, the Lupinus diffusate did not appear so beneficial.

\section{Experiments with the embryos of other plants}

Embryos of various plants other than Datura were cultured on the media with and without Lupinus diffusate (Table 1 and Figs. 3-6).

In the cultures of embryos of Pharbitis, Bidens, and Antirrhinum, sucrose concentration in the basal media was $20 \mathrm{~g} / l$, and casein hydrolysate was also tested. About two weeks old embryos of Pharbitis were green, spade-shaped, and $0.7-0.3 \mathrm{~mm}$ long. A larger amount of growth of the embryos was observed on the Lupinus medium than on casein hydrolysate medium. All embryos on the Lupinus medium continued to grow in a prolonged culture, but the development of plumule and root was strongly inhibited. For the growth of Bidens embryos the stimulative activity of Lupinus diffusate was inferior to that of casein hydrolysate. In the case of $A n$ tirrhinum, casein hydrolysate was rather inhibitory, but the Lupinus diffusate appeared slightly stimulative. The responses of the embryos of Pharbitis, Bidens and Antirrhinum to casein hydrolysate were quite different.

In Lupinus, Stellaria and Triticum, the effect of Lupinus diffusate which was decolorized with charcoal was compared with that of a crude one. Young Lupinus embryos of $1 \mathrm{~mm}$ were green at the start of experiment. On the basal medium they became pale in color in a few days and could not grow. On both media with decolorized diffusate and with crude one, however, all embryos were green. The growth of embryos in the decolorized diffusate was superior to that in the crude one. The growth-promoting factor of the diffusate was not adsorbed by charcoal. In the case of Stellaria (Fig. 3) the embryos grew well on the basal medium, and often developed roots in a few days. Crude diffusate was inhibitory, but the growth in the decolorized diffusate was stimulated slightly. In the experiment with Triticum, of which dates were not shown in Table, similar response as in the case of Stellaria was observed. On the basal medium the embryos grew into feeble seedlings. In crude diffusate most embryos stopped to grow. In the decolorized diffusate some embryos developed later shoot and root, and seedlings on this medium were more vigorous than those on the basal medium.

The Lupinus diffusate was favorable for the growth of embryos of Brassica and Capsella, and was slightly so for that of Astragalus (Figs. 4-6). In the case of Iris, the Lupinus diffusate was quite inhibitory. On the basal medium all the embryos grew into healthy seedlings, while no embryos could grow on the Lupinus medium. For the embryos of Vicia faba the diffusate was ineffective. In a week all embryos on any media stopped to grow, showing color change from green to brown. Vicia sativa embryos did not grow on any media.

By the use of coconut milk and malt extract, it has become easier to obtain hybrid plants from genetically incompatible crosses $^{15-17)}$. The cultivation of hybrid embryos from a cross of somatoplasmic sterility, Brassica pekinensis $\times$ B. chinensis, was attempted in co-operation with Mr. Nobumichi Inomata in the Laboratory of Genetics, Faculty of Agriculture, Kyoto University. Most of the embryos died in one or two weeks after pollination, because of the collapse of endosperm tissue during seed development. Viable seed can be scarcely obtained from this cross.

Hybrid embryos of $0.2 \mathrm{~mm}$ in length were cultured on the media with and with- 
out Lupinus diffusate. The development of the embryos was strongly promoted by the diffusate, and healthy seedlings could be obtained, which were grown into adult plants by Mr. Inomata.

In the present experiment, the Lupinus diffusate strongly promoted the growth of the embryos of Pharbitis, Bidens, Brassica, Lupinus, Capsella and of hybrid embryos obtained from Brassica plants. However, it was slightly effective in Stellaria, Antirrhinum, Astragalus and Triticum, nearly ineffective in Vicia faba and V. sativa, and inhibitory in Iris.

3. Effect of Lupinus diffusate on the growth of callus tissue of carrot root

Growth-promoting activity of Lupinus diffusate added to the basal medium was tested in the culture of callus tissue of carrot root. As controls, the basal media with and without $1 \mathrm{ppm}$ of kinetin were employed.

The Lupinus diffusate promoted the growth of isolated callus tissue remarkably. Stimulative activity of kinetin was inferior to that of the diffusate (Table 2 and Fig. 7).

Table 2. Effect of Lupinus diffusate $(2 \mathrm{~g}$ seed $/ 100 \mathrm{ml})$ and kinetin $(1 \mathrm{ppm})$ on the growth of isolated callus tissue of carrot root. The callus tissue of which initial fresh weight was $7.2 \mathrm{mg}$ was cultured at $26^{\circ}$ in darkness for 23 days.

\begin{tabular}{l|c|c|c}
\hline \multicolumn{1}{c|}{ Medium } & $\begin{array}{c}\text { Number of } \\
\text { tissues cultured }\end{array}$ & $\begin{array}{c}\text { Final fresh } \\
\text { weight (mg) }\end{array}$ & $\begin{array}{c}\text { Final dry } \\
\text { weight (mg) }\end{array}$ \\
\hline Basal medium (B. M.) & 9 & 27.9 & 3.2 \\
B. M. + Lupinus diffusate & 9 & 106.0 & 8.6 \\
B. M. + kinetin (1 ppm) & 9 & 56.3 & 7.0 \\
\hline
\end{tabular}

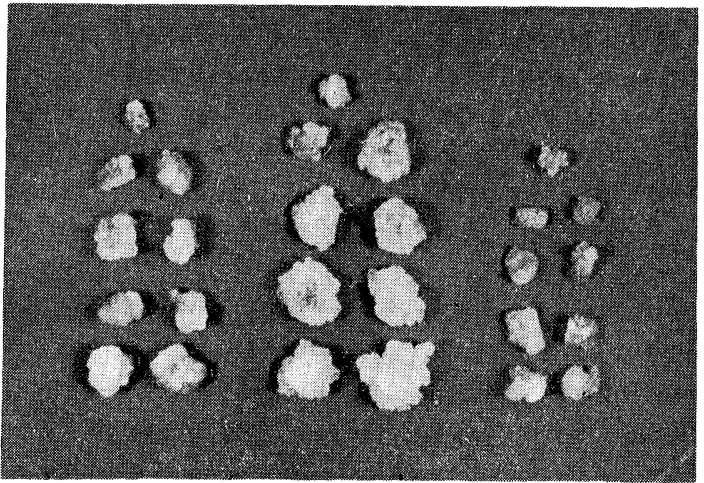

Fig. 7. Effect of Lupinus diffusate on the growth of isolated callus tissue of carrot root. Left, kinetin $1 \mathrm{ppm}$; center, Lupinus diffusate $(2 \mathrm{~g}$ seed $/ 100 \mathrm{ml})$; right, control.

\section{Growth-promoting factor in different plant materials}

Embryo factor activity of ethanol diffusates of young seeds of various plants and of fruits of Brassica was examined (Table 3). Young Datura embryos were cultured on the medium containing each diffusate at the concentrations corresponding 5 and 10 or $20 \mathrm{~g}$ of material per $100 \mathrm{ml}$. Growth-promoting activity was found in most of the materials. In the case of Glycine, the diffusate at a higher concentration was very inhibitory. The stimulative activity in fruit diffusate from Brassica was slight. 
Table 3. Effect of ethanol diffusates from young seeds or fruits of various plants on the growth of young Datura embryos. Diffusates obtained from 5 and 10 or $20 \mathrm{~g}$ materials were sterilized with Seitz-filter and added to $100 \mathrm{ml}$ of the basal medium. Datura embryos were cultured at $30^{\circ}$ in darkness for 5 days.

\begin{tabular}{|c|c|c|c|c|c|}
\hline Diffusates from & $\begin{array}{l}\text { Conc. } \\
\mathrm{g} / 100 \mathrm{ml}\end{array}$ & $\begin{array}{l}\text { Number of } \\
\text { embryos } \\
\text { observed }\end{array}$ & $\begin{array}{l}\text { Initial } \\
\text { length } \\
(\mathrm{mm})\end{array}$ & $\begin{array}{l}\text { Final } \\
\text { length } \\
(\mathrm{mm})\end{array}$ & $\begin{array}{c}\text { Growth } \\
\text { value }\end{array}$ \\
\hline Glycine soja & $\begin{array}{r}0 \\
5 \\
20\end{array}$ & $\begin{array}{r}15 \\
7 \\
9\end{array}$ & $\begin{array}{l}0.29 \\
0.27 \\
0.27\end{array}$ & $\begin{array}{l}1.78 \\
4.44 \\
0.27\end{array}$ & $\begin{array}{r}6.1 \\
16.4 \\
1.0\end{array}$ \\
\hline $\begin{array}{l}\text { Phaseolus } \\
\quad \text { vulgaris }\end{array}$ & $\begin{array}{r}0 \\
5 \\
20\end{array}$ & $\begin{array}{r}9 \\
11 \\
7\end{array}$ & $\begin{array}{l}0.28 \\
0.24 \\
0.27\end{array}$ & $\begin{array}{l}1.63 \\
3.06 \\
3.12\end{array}$ & $\begin{array}{r}5.8 \\
12.7 \\
11.9\end{array}$ \\
\hline $\begin{array}{l}\text { Phaseolus } \\
\text { vulgaris, } \\
\text { "Black Valentine" }\end{array}$ & $\begin{array}{r}0 \\
5 \\
20\end{array}$ & $\begin{array}{r}11 \\
9 \\
11\end{array}$ & $\begin{array}{l}0.25 \\
0.22 \\
0.25\end{array}$ & $\begin{array}{l}1.01 \\
1.60 \\
1.72\end{array}$ & $\begin{array}{l}4.0 \\
7.3 \\
6.9\end{array}$ \\
\hline $\begin{array}{l}\text { Brassica } \\
\text { campestris } \\
\text { (fruit) }\end{array}$ & $\begin{array}{r}0 \\
5 \\
20\end{array}$ & $\begin{array}{r}11 \\
10 \\
6\end{array}$ & $\begin{array}{l}0.19 \\
0.21 \\
0.20\end{array}$ & $\begin{array}{l}0.79 \\
1.24 \\
1.17\end{array}$ & $\begin{array}{l}4.2 \\
5.9 \\
5.9\end{array}$ \\
\hline Pisum sativum & $\begin{array}{r}0 \\
5 \\
20\end{array}$ & $\begin{array}{l}6 \\
7 \\
9\end{array}$ & $\begin{array}{l}0.25 \\
0.26 \\
0.29\end{array}$ & $\begin{array}{l}1.18 \\
2.97 \\
4.00\end{array}$ & $\begin{array}{r}4.7 \\
11.4 \\
13.8\end{array}$ \\
\hline Arachis hypogaea & $\begin{array}{r}0 \\
5 \\
20\end{array}$ & $\begin{array}{r}10 \\
9 \\
9\end{array}$ & $\begin{array}{l}0.23 \\
0.24 \\
0.25\end{array}$ & $\begin{array}{l}1.45 \\
3.61 \\
4.34\end{array}$ & $\begin{array}{r}6.3 \\
15.1 \\
17.4\end{array}$ \\
\hline $\begin{array}{l}\text { Canavalia } \\
\text { ensiformis }\end{array}$ & $\begin{array}{r}0 \\
5 \\
20\end{array}$ & $\begin{array}{r}10 \\
10 \\
9\end{array}$ & $\begin{array}{l}0.23 \\
0.23 \\
0.24\end{array}$ & $\begin{array}{l}1.45 \\
1.60 \\
3.14\end{array}$ & $\begin{array}{r}6.3 \\
7.0 \\
13.1\end{array}$ \\
\hline Lupinus luteus & $\begin{array}{r}0 \\
5 \\
10\end{array}$ & $\begin{array}{l}10 \\
10 \\
10\end{array}$ & $\begin{array}{l}0.26 \\
0.21 \\
0.19\end{array}$ & $\begin{array}{l}0.63 \\
5.10 \\
4.83\end{array}$ & $\begin{array}{r}2.4 \\
24.3 \\
25.4\end{array}$ \\
\hline
\end{tabular}

\section{Discussion}

Coconut milk stimulates the growth of isolated young embryos and cultured callus tissues $^{1-8)}$. In the culture of immature Datura embryos, malt extract can be substituted for coconut milk ${ }^{15}$. Yeast extract, wheat germ, almond meal and Datura ovule contain also embryo factors ${ }^{9)}$. Hordeum endosperm contains some factor stimulating the growth of embryos of Raphanus and Capsella as well as that of Hordeum $^{18)}$. In the present study, it is demonstrated that the ethanol diffusate of Lupinus seed, which stimulates the growth of Datura embryo, is also affecting the growth of the embryos of various plants and that of callus tissue of carrot root. Similar growth-promoting substance is found in seeds of many plants. The effectiveness of the Lupinus diffusate, however, is variable according to specific differences among the embryo used. It is less effective for the embryos of Stellaria, Astragalus, Vicia $f a b a$, and Triticum, and is inhibitory to the embryo of Iris. Such is also the case with casein hydrolysate. It was stimulative to the growth of Bidens and Pharbitis, and inhibitory to that of Antirrhinum. This may be attributed to the following reasons.

Some factors and cultural conditions which mask the growth-promoting activity 
are frequently reported. Coconut milk contains at least three growth factors for young Datura embryo; the first heat-unstable component which promotes embryo growth, the second heat-stable one which induces callus-type growth, and the third heat-stable one inhibitory to root growth ${ }^{1)}$. Solomon (1950) showed that malt extract contained a heat-stable growth-promoting factor for Datura embryo, the activity of which, however, was masked by the inhibitor formed during autoclaving ${ }^{19)}$. Neither the growth-promoting factor of Lupinus diffusate was destroyed nor its activity was masked by heat sterilization. It contains a factor which inhibits the growth and suppresses the precocious germination of immature embryos of Triticum and Stellaria, and this factor may be removed partially by charcoal treatment. The embryos of different plants may be different in sensitivity to the inhibitory substance contained in the crude diffusate.

The effectiveness also differs according to the age of embryo. Very young globular Datura embryos less than $0.08 \mathrm{~mm}$ in length can not be cultured by the use of crude Lupinus diffusate. It promotes the embryo growth in heart-shaped stage strongly, but not that in later stages. Embryos of different species or different age may require different concentrations of a growth factor or a different growth factor.

As to the chemical nature of these active substances in coconut milk, 1,3-diphenylurea $^{201}$, leucoanthocyanin ${ }^{11)}$ and myo-inositol ${ }^{21)}$ were isolated as growth-promoting substances for tissues of carrot root. Ziebur and Brink (1951) arrived at the conclusion that the embryo factor in Hordeum endosperm is different from that in coconut milk and malt extract ${ }^{18)}$.

The Lupinus diffusate is stimulative to the growth of embryos of various plants, and a growth factor or factors of similar activity is distributed widely in seeds of a number of species of plants. The growth of callus tissue of carrot root was also promoted by Lupinus diffusate. Whether two growth-promoting activities, one for embryo and the other for callus tissue, are due to the same factor, as suggested by Steward $e t a l .{ }^{22)}$, or to different substances, remains to be investigated.

\section{Summary}

1. The optimum concentration of Lupinus diffusate, which contanis growthpromoting factor for young Datura embryo in vitro, is equivalent to $10 \mathrm{~g}$ of Lupinus seed $/ 100 \mathrm{ml}$ of the medium.

The growth-promoting factor in the Lupinus diffusate is not destroyed by autoclaving at $1.0 \mathrm{~kg} / \mathrm{cm}^{2}$ overpressure for ten minutes.

The Lupinus diffusate promotes remarkably the growth of young Datura embryos, but not the old ones.

2. By Lupinus diffusate, the growth of embryos of Pharbitis nil, Bidens biternata, Brassica campestris, Lupinus luteus, Capsella bursa-pastoris and of hybrid embryos from a genetically incompatible cross of Brasssca pekinensis $\times$ B. chinensis are promoted remarkably. This diffusate is slightly effective for the growth of embryos of Stellaria media, Antirrhinum majus, Astragalus sinicus, and Triticum aestivum, nearly ineffective to that of Vicia faba and V. sativa, and inhibitory to Iris pseudoacorus.

3. In Stellaria and Triticum, the Lupinus diffusate supports embryonal growth and prevents precocious germination.

4. The Lupinus diffusate promoted the growth of cultured callus tissue of carrot root. 
5. Similar embryo factor activity was found in the ethanol diffusates of seeds of Glycine soja, Phaseolus vulgaris var. humilis and "Black Valentine", Arachis hypogaea, Pisum sativum, Canavalia ensiformis and of fruits of Brassica campestris.

The author is indebted to Professor S. Imamura and Assistant Professor M. Hamada for their guidance and counsel during the course of this study.

\section{References}

1) Van Overbeek, J., Conklin, M. E., and Blakeslee, A. F., Amer. J. Bot. 29: 472 (1942). 2) Ball, E., ibid. 33: 301 (1946). 3) Caplin, S. M., and Steward, F. C., Science 108: 655 (1948). 4) Nickell, L. G., Bot. Gaz. 112: 225 (1950). 5) Morel, G., and Wetmore, R. H., Amer. J. Bot. 38: 138 (1951). $\quad$ 6) Henderson, J. H. M., Durrell, M. E., and Bonner, J., ibid. 39: 467 (1952). 7) Tulecke, W., ibid. 44: 602 (1957). 8) Norstog, K., ibid. 48: 876 (1961). 9) Van Overbeek, J., Siu, R., and Haagen-Smit, A. J., ibid. 31: 219 (1944). 10) Steward, F. C., and Simmonds, N. W., Nature 173: 1083 (1954). 11) Shantz, E. M., and Steward, F. C., Plant Physiol. 30: (Suppl.) xxxv (1955). 12) Matsubara, S., Bot. Mag. Tokyo 75: 10 (1962). 13) Paris, D., Rietsema, J., Satina, S., and Blakeslee, A. F., Proc. Natl. Acad. Sci. 39: 1205 (1953). 14) Matsubara, S., Bot. Mag. Tokyo 77: 253 (1964). 15) Blakeslee, A. F., and Satina, S., Science 99: 331 (1944). 16) McLean, S. W., Amer. J. Bot. 33: 630 (1946). 17) Blakeslee, A. F., and Satina, S., ibid. 34: 580 (abstract) (1947). 18) Ziebur, N. K., and Brink, R. A., ibid. 38: 253 (1951). 19) Solomon, B., ibid. 37: 1 (1950). 20) Shantz, E. M., and Steward, F. C., Jour. Amer. Chem. Soc. 77: 6351 (1955). 21) Pollard, J. K., Shantz, E. M., and Steward, F. C., Plant Physiol. 36: 492 (1961). 22) Steward, F. C., and Shantz, E. M., Ann. Rev. Plant Physiol. 10: 379 (1959).

\section{摘 要 \\ 松 原 聡： 種々の植物幼胚とニンジンの培養組織の生長におよぼすルピナス 生長促進物質の效果}

1）チョウセンアサガオの幼胚の生長には, $10 \mathrm{~g}$ のルピナス種子の浸出液が $100 \mathrm{ml}$ の培養基に含ま れるとき最適濃度であり, 浸出液汁の生長促進物質は $1.0 \mathrm{~kg} / \mathrm{cm}^{2} 10$ 分間の加圧隇菌に耐える. 浸出液は 若い胚の生長をとくに促進する。

2) ルピナス浸出液は，アサガオ，センダングサ，ナタネ，ルピナス，ナズナの幼胚やブラシカ属の不 稔交雑の幼肧, ニンジンの根の培養カルスなどの生長を促進する。、、ベ, キンギョソウ, レンゲソウ, コムギの幼肧には効果が少なく, ソラマメ, キショウブ, カラスノェンドウの幼脹には效果はない.

3) ダイズ, インゲン, ナンキンマメ，エンドウ，ナタマメの若い種子やナタネの実のエタノ一ル浸出 液にも同様な幼胚生長促進の効果がある。（京都大学農学部応用植物学研究室, 現所属: 京都府立大学生物 学教室) 